\title{
Marcin Rycek
}

M.Sc., PhD student at the Doctoral School of the Catholic University of Lublin, Institute of Canon Law, Catholic University of Lublin https://orcid.org/0000-0003-3090-3166

\section{CAN A COFFEE BURN WHILE TRAVELING BY AIR BE AN ACCIDENT? ANALYSIS OF THE JUDGMENT OF EU COURT OF JUSTICE IN C-532/18 GN V NIKI LUFTFAHRT GMBH}

\begin{abstract}
In a judgement of 19 December 2019, C-532/18, ${ }^{1}$ in the case GN represented by father HM, against Niki Luftfahrt GmbH, the Court of Justice stated that an accident is any incident occurring on board an airship in which an object used for the use of an on-board service caused damage the passenger's body, and it is irrelevant as to how the hazard typical of air transport materialized. The mere fact of suffering damage during air travel is sufficient for the court to find that an accident has occurred.
\end{abstract}

Keywords: Montreal Convention, accident, concept, hazard, air travel. 


\section{Introduction}

The analysed judgement concerns the interpretation of article 17(1) of the Montreal Convention ${ }^{2}$ and the meaning of the concept of an accident. The Montreal Convention was adopted to harmonize certain rules on international air transport. It also aims to modernize and consolidate the Warsaw Convention ${ }^{3}$ for the harmonization of private international law carriage by air. On 9 December 1999, the Montreal Convention was signed by the European Community, and by the decision of the Council of the European Union 2001/539/EC of 5 April 2001, it was approved on its behalf. It therefore, forms an integral part of the EU legal order, which is why the Court of Justice has jurisdiction to give a preliminary ruling on its interpretation. ${ }^{4}$ The already called Article 17(1) of the Montreal Convention does not contain a legal definition of the concept of an accident, ${ }^{5}$ but only makes the carrier liable for damage if an injury occurred on board the aircraft or during any of the operations of embarking and disembarking. There is also no existence of the acte clair in the cited convention or acte éclairé to a case like this, which is why the Oberster Gerichtshof ${ }^{6}$ asked the Court of Justice of the European Union to clarify how to understand the concept of 'accident' in the Montreal Convention.?

\section{Analysed European Union law and international law}

In the analysed judgement, the Court of Justice of the European Union interpreted the notion of an accident contained in Article 17(1) of the Montreal Convention. That interpretation was given because of the question

2 Convention for the unification of certain rules for international carriage by air, OJ L 194, 18 July 2001, p. 39-49.

3 The Warsaw Convention is the informal title for the Convention Unification of Certain Rules Relating to International Transportation by Air, signed in Warsaw 12 October 1929, T.S. no. 876, 137 L.N.T.S. 11, reprinted in 49 U.S.C.A.

4 C-6/14, Wucher, EU:C:2015:122.

5 Case law based on the Warsaw Convention defined the accident as 'an emergency caused by an external action resulting in the death of or being injured', See Konert, 'Terroryzm lotniczy - problematyka kompensacji szkód', 80-81.

6 Austrian Supreme Court.

7 C-532/18 Niki Luftfahrt, EU:C:2019:1127, para. 27. 
referred for a preliminary ruling by the Oberster Gerichtshof is if the term 'accident' within the meaning of Article 17(1) of the Montreal Convention form the basis of the carrier's liability, wherein a situation in which a cup with hot coffee placed on the fold-down table of the back of the seat in front of a person in an aircraft, for unknown reason slid and tipped over, causing a passenger to suffer scalding.

The Montreal Convention states that, at the time of signing this Convention, the signatories recognize the need to guarantee the protection of consumers' interests in international air transport ${ }^{8}$ and, therefore, guarantee fair compensation based on the principles of compensation. The Convention also indicates that this collective action of states for further harmonization and codification of rules regarding international air transport is the best means to achieve a fair balance of interest. ${ }^{9}$

When examining Article 17(1) of the Montreal Convention, the Court of Justice has held that an air carrier is liable for damage caused by the death or personal injury of a passenger, only if the accident occurs on board or during any operation involving disembarkation or embarkation. ${ }^{10}$ However, the law always gives the possibility of defence to the responsible party, which is why Article 20 of the Montreal Convention provides for the possibility of the carrier being released from liability in whole or in part, if it proves that the damage was caused by the negligence, omission or other unlawful action of the person claiming compensation, depending on the extent of the contribution. It should also be noted that Article 21 of the Montreal Convention provides that the carrier shall not waive its liability if the damage arising from Article 17(1) does not exceed 100000 special drawing rights. ${ }^{11}$ If the value of damage exceeds this amount, the carrier has the right to evade this liability in a similar way as in Article 20 of this Convention. ${ }^{12}$ When interpreting international law, we should also take into account Article 29 of the Montreal Convention, which for

8 Para. 3.

9 Para. 5; C-532/18 Niki Luftfahrt, EU:C:2019:1127, paras. 3-4.

10 Jaworek, 'Problematyka odpowiedzialności Skarbu Państwa oraz innych podmiotów za szkody wyrządzone na skutek zderzenia statków powietrznych ze zwierzętami', 147-148.

11 'Special drawing rights' is an arbitrary monetary unit having the character of non-cash money existing in the form of accounting entries on bank deposit accounts created in 1967 to stabilize the international monetary system.

12 C-532/18 Niki Luftfahrt, EU:C:2019:1127, paras. 5-7; Żylicz, Prawo lotnicze międzynarodowe, europejskie i krajowe, 85-86. 
the justification of an action for damages in the carriage of passengers, requires the initiation of proceedings subject to the conditions and limits of liability provided for in the Montreal Convention - and no other noncompensatory damages may be awarded in such judicial proceedings. ${ }^{13}$

As we move toward the interpretation of EU law, we should start by recalling that, as a result of the signing of the Montreal Convention, Council Regulation No $2027 / 97^{14}$ of 9 October 1997 on air carrier liability for the carriage of passengers and their baggage by air was amended by Regulation No 889/2002 of the European Parliament and the Council of 13 May 2002. ${ }^{15}$

According to Regulation 889/2002, recital 7 states that the Montreal Convention strengthens the protection of passengers and their dependents and cannot be interpreted as weakening their protection in current legislation. Besides, recital 10 states that a system of unlimited liability in the case of death or injury of a passenger is fair in accordance with a safe and modern air modern transport system. European Union law in Regulation No 2027/97 also does not define the concept of an accident and in Article 2 of the said regulation, in the case of the use of undefined terms in the regulation, there is a reference to the use of the concepts contained in the Montreal Convention. Moreover, in Article 3(1) of Regulation No 2027/97, there is a reference stating that the issue of liability of an air carrier operating in the European Union is subject to liability under the Montreal Convention. ${ }^{16}$

\section{National proceedings and request for a preliminary ruling}

The case discussed concerned the claims of an underage girl who in 2015 was flying with her family by plane. When the stewardess served drinks, the girl sat by the window and leaned on the armrest of her father's chair. Her father took a paper cup from the stewardess, that was without a lid and which was filled with freshly brewed coffee. He set it down on the folddown table attached to the back of seat in front. He then asked for milk, and both the stewardess and the child's father noticed that the coffee cup had began to slide off the table and tried to prevent it. However, the cup fell 
over and spilled onto the right thigh and chest of the child, who suffered second-degree burns covering around 3\% of her body's surface. The evidence did not determine whether the cup slid off the table due to vibration or whether the table was defective or incorrectly positioned. The parents demanded compensation for the accident. The airline, however, decided that the unexpected event did not lead to the sliding of the coffee mug and there is no materialization of a hazard risk typical of air transport. ${ }^{17}$

The liability of airlines under the Montreal Convention is due to the fact that the place of departure and destination for this flight are located in the area of two States Parties to the Convention (Spain, Austria), so we are dealing with international transport within the meaning of Article 1 of the Convention Montreal. An additional argument is a fact that the EU Member States are liable for damage under the Montreal Convention. ${ }^{18}$ In the present case, it was disputed whether the liability of air carriers could be limited to cases in which the hazard typical of air transport materializes.

\section{Arguments of the Court of Justice}

The Court of Justice was to establish an understanding of the concept of an accident based on the question referred for a preliminary ruling. The CJEU considered that according to Article 17(1) of the Montreal Convention, the concept of an accident should be understood as any situation in which an object used for the use of an on-board service caused harm or injury to the body of a passenger in any case, without the necessity of determining whether this is the result of risk typical of air transport. Specifying we speak here about the liability of air carriers about the air transport of passengers and their luggage within the territory of the Union. This is in accordance with Article 3(1) of Regulation No 2027/97, which refers to the application of the Montreal Convention provisions on the liability of the carrier, also by current case-law. ${ }^{19}$

17 The turbulence or breakdown of aircraft, including the analysis of the material risks typical of air transport, should also take into account the changes in aircraft height or speed, C-532/18 Niki Luftfahrt, EU:C:2019:1127, paras. 13-17.

18 Declarations by the European Community recognized the provisions of the Montreal Convention, https://www.icao.int/secretariat/legal/List\%20of\%20Parties/ Mt199_FR.pdf (accessed 10 June 2020).

19 C-532/18 Niki Luftfahrt, EU:C:2019:1127, paras. 28-29; C-63/09 Walz, EU:C:2010:251.. 
The provisions of the Montreal Convention into the European Union's legal order entered into force on 28 June 2004 and are now an integral part of its legal order, hence the Court's legal standing to interpret the provisions of that convention. ${ }^{20}$ Interpretation of international agreements should be done in good faith, ${ }^{21}$ in accordance with the usual meaning attached to the words used in their context. The subject and purpose of the contract should also be considered. ${ }^{22}$ According to the Court's arguments, the concepts contained in the Montreal Convention should be interpreted uniformly and autonomously, without paying attention to the meanings assigned to them in the Member States. It is the interpretation of universal international law that is binding on the Court. ${ }^{23}$ Hence, the concept of an accident under Article 17(1) of the Montreal Convention should be given the usual meaning and defined as 'an unforeseen, unintentional injury event'. According to the third and fifth paragraphs of the Convention already cited, the unlimited liability of air carriers is due to the necessity of maintaining a fair balance of interests, including both the interests of carriers and passengers. ${ }^{24}$

To maintain an appropriate balance, the Montreal Convention, in some cases, gives the carrier the option of relieving the carrier of its liability, in accordance with Article 20 and Article 21 of that Convention. The carrier must, however, demonstrate that the damage did not occur as a result of its failure or was caused by the activities of a third party. This solution is extremely beneficial for passengers, because it allows passengers to obtain compensation quickly and easily, and does not impose an excessive obligation on air carriers to repair the damage, as this could greatly complicate their business operations. ${ }^{25}$

20 C-258/16 Finnair, EU:C:2018:252, paras. 19-20.

21 Article 31 of Vienna Convention on law of treaties, 23 May 1969, United Nations Treaty Series, vol. 1155, p. 331.

22 C-258/16 Finnair, EU:C:2018:252, para. 21.

23 C-213/18 Adriano Guaitoli, EU:C:2019:927, para. 47.

24 In the Montreal Convention, we use the concept of an accident, not an event, because it is too broad and therefore was removed in the preparatory work in the last sentence of Article 17 (1) regarding the carrier's lack of liability when the death or injury of a passenger would result from his state of health; C-63/09 Walz, EU:C:2010:251, paras. 31-33; C-410/11 Espada Sanchez, EU:C:2012:747, para. 47; C-532/18 Niki Luftfahrt, EU:C:2019:1127, paras. 30-38.

25 C-63/09 Walz, EU:C:2010:251, paras. 34-36; C-410/11 Espada Sanchez, EU:C:2012:747, para. 30. 
It is also impossible to disagree with the opinion of the Advocate General, ${ }^{26}$ who in para. 60 indicates the relationship between the liability of the carrier and the fulfilment of the requirement for the occurrence of damage, i.e. materialization of risk or the existence of a relationship between the accident and the movement of the aircraft. Therefore, the Court stated that the concept of accident covers any situation occurring on board an aircraft in which an object used for the use of an on-board service caused injury to a passenger, without having to determine whether these situations are the result of risks typical of air services. ${ }^{27}$ However, this does not cause too much obligation to repair the damage, because the carrier has the right to be released from liability. ${ }^{28}$

\section{Assessment}

In the present judgement, the Tribunal interpreted the concept of an accident, and the cited decision has practical significance for every potential airline traveler. The Court clearly stated that the concept of accident applies to all damages that arise, not only those related directly to the flight. In the current interpretation of the Court, when a passenger causes or causes damage himself, only then can the carrier be released from liability. This is justified by the literal interpretation of the concept because the Montreal Convention does not require the occurrence of the disputed event due to the risk typical for air transport. The air properties of the ship and its wear are not important either. ${ }^{29}$

The concept of an accident, although it has been used extensively in the convention, ${ }^{30}$ is not given a precise definition throughout the text, so it should be understood according to its ordinary, everyday meaning. ${ }^{31}$ Of course, the plaintiff in the proceedings must prove that the incident that

26 C-532/18 Niki Luftfahrt, ECLI:EU:C:2019:788.

27 C-532/18 Niki Luftfahrt, EU:C:2019:1127, para. 43.

28 C-532/18 Niki Luftfahrt, EU:C:2019:1127, paras. 39-42.

29 Article 2 containing the definitions of the accident from Regulation No. 996/2010, OJ L 295, 12 November 2010, p. 35-50.

30 Article 17(1), Article 28, Article 33(2 and 3), Article 36(2) of the Montreal Convention.

31 Another view on this has the Court of Appeal dealing with this case. In his opinion, the accident in Article 17 (1) of the Montreal Convention is an incident that is subject to aviation-specific hazard risks such as turbulence or aircraft breakdown. Grigorieff, 'Le regime d'indemnisation de la convention de Montreal', 662-665. 
occurred during the air transport caused damage and can be considered an accident. ${ }^{32}$ Similarly, they also must understand the concept of an accident as used by American courts, which considered a hot drink falling over on a passenger to be an accident. ${ }^{33}$

The Court of Justice of the European Union, in interpreting the term 'accident' on a teleological basis has come to similar conclusions. The purpose of the Montreal Convention is to harmonize regulations in the field of air carrier liability. There is a legal requirement that allows for bringing actions for damages only under the terms and following the Montreal Convention, which excludes the possibility of applying national law contrary to the provisions of this Convention. ${ }^{34}$ Furthermore, in the opinion of the Advocate General, we find the interpretation that the interpretation of the concept of an accident should be conducted in such a way that it does not lead to claims for damages based on the provisions of the Convention not being subject to restrictive conditions that the authors of that convention did not intend. ${ }^{35}$ It should also be borne in mind Recital 7 of Regulation 889/2002, which indicates that the provisions on passenger protection should be interpreted in favour of them and their dependents. Thus, passengers have the right to fair compensation for inflicted damage, based on the 'principle of compensation,, ${ }^{36}$ as well as the right to strive for a 'fair balance of interests'. ${ }^{37}$ This is why the EU Member States have decided to adopt a restrictive system of airline liability, while attempting to ensure a balance between the interests of passengers and air carriers. ${ }^{38}$

The principle of Community law effet utile ${ }^{39}$ should also be borne in mind, and if we were to assume that the accident under Article 17(1) of the

32 Reuschle, Montrealer Ubereinkommen - Kommentar, 13.

33 U.S. District Court of Puerto Rico 17.6.1988, Diaz Lugo v. American Airlines, https:// law.justia.com/cases/federal/district-courts/FSupp/686/373/1362396/ (accessed 10 June 2020); C-532/18 Niki Luftfahrt, ECLI:EU:C:2019:788, paras. 36-47.

34 Only Article 29 of the Montreal Convention contains an exception to this rule, referring to the provisions of national law regarding the determination of the procedural capacity and rights of the plaintiff.

35 C-532/18 Niki Luftfahrt, ECLI:EU:C:2019:788, paras. 50-51.

36 Para. 3.

37 Para. 5.

38 C-258/16 Finnair, EU:C:2018:252, para. 43; C-410/11 Espada Sanchez, EU:C:2012:747, paras. 29-30; C-63/09 Walz, EU:C:2010:251, para. 30; C-532/18 Niki Luftfahrt, ECLI:EU:C:2019:788, paras. 48-51.

39 'The Practical effectiveness of European Community law', is the principle requiring daily effectiveness in the provision of European law. See Nowak - Far, 'Effet 
Montreal Convention would have characteristics peculiar to air transport, it would violate the rights of passengers. Airline passengers do not have access to all information containing aircraft technical data or to its consumption. In addition, it should be borne in mind that such requirements would exclude many phenomena from the concept of an accident. Airlines could only be held liable in the event of severe turbulence or crashing of the aircraft, so it is therefore not necessary that the consumption of vessels affect whether an accident has occurred. ${ }^{40}$

The contextual interpretation also leads to similar conclusions. Article 17(1) of the Montreal Convention explicitly indicates the liability of an air carrier for damage, and if the amount for the damage does not exceed 100,000 special drawing rights, the carrier cannot avoid objective liability. Above this threshold, to be free from fault, the carrier must demonstrate that the fault cannot be attributed to it, but to the injured party or a third party. The legal solutions applied are beneficial to injured passengers, as they are only required to prove the damage suffered and the cause-effect relationship of the accident with the damage caused; they do not have to prove the fault of the air carrier. Airline passengers also do not need to show that there is a typical risk to air transport or that the accident has occurred due to aircraft wear. The analysis of system provisions regarding the liability of carriers for damage leads to the conclusion that they are aimed at strengthening passenger protection. ${ }^{41}$ The Montreal Convention does not provide for a quantitative limitation on the amount of compensation, ${ }^{42}$ this is to increase liability and to strive to more equitable damages arising. ${ }^{43}$

Analysis of the concept of accident leads to the conclusion that it is not necessary to materialize the hazard typical of air transport to the occurrence of an accident. Aviation regulations must have a uniform liability

utile obowiązek bezpośrednieego stosowania dyrektyw i wykładnia zgodna - relacje i ograniczenia w kontekście unijnego prawa zamówień publicznych', 4-12.

40 C-532/18 Niki Luftfahrt, ECLI:EU:C:2019:788, paras. 51-55; Konert, 'Odpowiedzialność przewoźnika lotniczego w przypadku turbulencji na gruncie orzecznictwa amerykańskiego’, 43-44.

41 See Article 17 in relation to Article 20 of the Warsaw Convention, which provided for a rebuttable presumption of the fault of an air carrier.

42 See Article 22 of the Warsaw Convention on maximum compensation; Grigorieff, 'Le regime d'indemnisation', 653-656.

43 Recitals 7 and 10; C-532/18 Niki Luftfahrt, ECLI:EU:C:2019:788, paras. 56-61. 
regime, without having to refer to national law each time. ${ }^{44}$ However, the air carrier still retains the right to be released from liability ${ }^{45}$ and is not unrestricted. Therefore, an accident is any event occurring on board an aircraft in which an object used for the purpose of in-flight service caused bodily injury to a passenger. A sine qua non condition for the occurrence of an accident is the damage suffered by the passenger during the air travel. ${ }^{46}$

\section{Bibliography}

1. Grigorieff, Cyril - Igor. 'Le regime d'indemnisation de la convention de Montreal', Revue europeenne de droit de la consommation , no. 4 (2012): 651-676.

2. Jaworek, Katarzyna. 'Problematyka odpowiedzialności Skarbu Państwa oraz innych podmiotów za szkody wyrządzone na skutek zderzenia statków powietrznych ze zwierzętami.', Ius Novum, no. 1 (2014): 143-162.

3. Konert, Anna. 'Odpowiedzialność przewoźnika lotniczego w przypadku turbulencji na gruncie orzecznictwa amerykańskiego.' , Ius Novum , no. 1 (2010): 39-51.

4. Konert, Anna. 'Terroryzm lotniczy - problematyka kompensacji szkód.', Państwo i Prawo, no. 7 (2003): 76-88.

5. Nowak - Far, Artur. 'Effet utile obowiązek bezpośrednieego stosowania dyrektyw i wykładnia zgodna - relacje i ograniczenia w kontekście unijnego prawa zamówień publicznych', Europejski Przegląd Sądowy, no. 6 (2017): 4-12.

6. Reuschle, Fabian. Montrealer Ubereinkommen - Kommentar, Berlin: De Gruyter, 2011.

7. Żylicz, Marek. Prawo lotnicze międzynarodowe, europejskie i krajowe, Warszawa: WKP, 2011.

44 See Article 24 of the Warsaw Convention, which did not exclude the application of national law.

45 Articles 21 and 22.

46 C-532/18 Niki Luftfahrt, EU:C:2019:1127, para. 43. 